\title{
CORRESPONDENCE
}

\section{Calls to counter science scepticism are irrelevant in India}

SIR - In the wake of Harry Collins's Essay 'We cannot live by scepticism alone' (Nature 458, 30-31; 2009) and the Correspondence it stimulated from several Western scholars (Nature 458, 702-703; 2009), I think it is also important to consider an Eastern viewpoint. Because of the notably different social set-up in India, Collins's call for studies to counter scepticism about science is irrelevant in this part of the world.

In an Indian context, my sense is that, in the significant segment of society for which such issues matter, science is neither the ultimate form of knowledge nor a victim of scepticism. Here, religion is the way of life. Even for many scientists and scholars of other disciplines, traditional religious values and philosophy are the unshakeable pillars in every domain of their lives, including science. Religion is a guard against the fear of future unknowns.

My observations as a research scientist of more than 30 years' standing suggest that most scientists in India conspicuously evoke the mysterious powers of gods and goddesses to help them achieve success in professional matters, such as publishing papers or gaining recognition. This is probably because factors outside their control come into play: religious endeavours offer comfort as well as being seen as a prerequisite for success.

In general, Indian society is not sceptical of science either - the common belief is that the boons of science outweigh any ill effects. After all, it has solved some of the toughest problems of humankind and has ushered in the era of technology-driven economies. It also addresses our curiosity and infuses a rational way of thinking into our societies. Acknowledging that uncertainty is an innate component of science should raise the standards and accuracy of scientific investigation, rather

than increasing scepticism.

Lalit M. Kukreja Homi Bhabha National Institute and Laser Materials Processing Division, Raja Ramanna Centre for Advanced Technology, PO CAT, Indore 452 013, India e-mail:kukreja@rrcat.gov.in

\section{Protecting the environment can boost the economy}

SIR - In attempting to sustain natural ecosystems, we should not assume that imposing a price on goods and services that adversely affect the environment will also have a negative effect on the economy. Placing a value on ecosystem services certainly changes the relative cost of various actions, but approaches being developed in other areas indicate that not all costs must necessarily rise.

Take the case of carbon emissions. Revenues from the sale of emissions permits to powergenerating companies can be returned to the economy through funding of research into cleanenergy technologies, say, or by returning money to the consumer - for example, under a 'capand-dividend' system that pays dividends to all taxpayers (whose environment is being damaged). This would alleviate the regressive nature of increased energy costs being passed on to consumers. For those purchasing 'green' power (wind, solar and hydro) generated with minimal carbon emissions, net costs would decrease.

Likewise, vehicle purchases could be governed by a 'feebate' system: those producing aboveaverage emissions would cost more, the extra 'fee' being used to provide rebates to buyers of lesspolluting vehicles.

There is no reason why ecosystem services could not be priced using comparable systems. For example, the fees paid for new development projects might be based on their environmental impact relative to some average, making developments cheaper if they can preserve valuable ecosystems or sequester carbon, and charging more to those that do not. Although goods and services having large adverse effects on the environment would increase in cost, those with minimal adverse effects would become relatively, or even absolutely, less expensive. And that, of course, is the whole point.

Drew Shindell NASA Goddard Institute for Space Studies, 2880 Broadway, New York 10025, USA

e-mail: drew.t.shindell@nasa.gov

\section{Time for China to restore its natural wetlands}

SIR - Your News story 'Putting

China's wetlands on the map'

(Nature 458, 134; 2009) points out that almost $30 \%$ of China's natural wetlands vanished between 1990 and 2000. It is time for the country to restore these natural wetlands and, in view of their ecological importance, to construct some artificial wetlands to supplement them.

Wetlands include tidal marshes, mangroves, swamps and flood plains. They contribute the largest sector of total terrestrial ecosystem services - for example, flood mitigation, water-quality improvement, habitat biodiversity and landscape aesthetics. Their alarming rate of disappearance in China can be blamed on conversion to farmland and on pollution from point and non-point sources.

China is putting a massive stimulus package in place to boost the economy, covering the infrastructure of transportation, medical care, education and industrial upgrading. Water regulation is also a vital investment target, and will help to meet the increasing demand for water and create employment. The merits of water-related programmes in Western countries, such as best-management practices and low-impact development, and of small-scale rainfall-collection systems could be useful models for China to study.

Hydroelectric power and the south-to-north water-diversion project will help to alleviate drought in the future, as will China's investment in natural and constructed wetlands, and in additional water resources such as farmland irrigation and drainage.

Xubin Pan Department of Environmental Engineering, Texas A\&M University Kingsville, Kingsville, Texas 78363, USA Bin Wang State Key Laboratory of Vegetation and Environmental Change, Institute of Botany, Chinese Academy of Sciences, Beijing 100093, China e-mail:wangbin07@gmail.com

\section{Erasmus Darwin saw sexual selection before his grandson}

SIR - I must leap to the defence of Charles Darwin's grandfather, Erasmus. It is not the case that, as David J. Hosken says in his Correspondence, "no one else envisaged anything like sexual selection" before Charles Darwin (Nature 458, 831; 2009). His grandfather had done so more than 50 years earlier.

In his book Zoonomia (Johnson, 1794), Erasmus writes: "the three great objects of desire, which have changed the forms of many animals by their exertions to gratify them, are those of lust, hunger, and security". Lust, he goes on, leads to sexual selection: male birds fight so that "the strongest and most active animal should propagate the species, which should thence become improved".

Erasmus is often lost behind the glare of his stellar grandson, but he should not be forgotten. In many ways, as readers of Zoonomia and his great poem 'Temple of Nature' will appreciate, he played John the Baptist to Charles's Jesus.

C. U. M. Smith Vision Sciences, Aston University, Birmingham B4 7ET, UK e-mail: c.u.m.smith@aston.ac.uk 